\title{
Analysis of Halal and Marketing Strategy for Broiler Chickens' Supply Chain during Covid-19 : A Case Study in Yogyakarta, Indonesia
}

\author{
Hayati Mukti Asih $^{1 *}$, Fahri Firmansyah², Muhammad Faishal ${ }^{1,2}$ \\ ${ }^{1}$ Faculty of Industrial Technology, Ahmad Dahlan University, \\ Jl. Ringroad Selatan, Kragilan, Tamanan, Kec. Banguntapan, Bantul, Yogyakarta, Indonesia 55191 \\ ${ }^{2}$ Faculty of Manufacturing Engineering, Universiti Teknikal Malaysia Melaka, \\ Jalan Hang Tuah Jaya, 76100 Durian Tunggal, Melaka, Malaysia
}

\begin{abstract}
Corona virus has a destructive impact on the world's economy, especially in Indonesia, making a large-scale social restriction policy (SRL). Many restaurants, hotels, schools, and colleges in Yogyakarta are closed. Consumers, mostly students from outside Yogyakarta, have to return to their hometowns. This case impacts the decline in chicken prices to cover losses due to excess supply and decreasing demand. This research aims to analyze the decline in chicken prices, halal products' and the concept of marketing strategies impact on the chicken supply chain during the Covid-19 outbreak in Yogyakarta. This research used SEM to obtain accurate analysis and descriptive results to overview phenomena from society under study. The analysis using SEM shows that halal factors do not significantly affect consumer decisions in buying chicken. However, it was found that there was an increase in consumers in online shopping, which could create new strategies in marketing strategies. The application of online marketing strategies will improve consumers' services so that it is expected to be a novel value that can increase consumer buying interest during the Covid-19 outbreak in Yogyakarta, Indonesia.
\end{abstract}

Keywords: COVID-19; food supply chain; halal; SEM; sustainability

\section{Introduction}

Muslim population is the largest religious group in the world. According to a study in 2015, muslims population is 1.8 billion, which makes $24 \%$ of the world's population. The opportunities for the market for halal products are increasing. It has been due to an increased population and increased purchasing power of the World's Muslim community (Lipka \& Hackett, 2017). Indonesia is a country with the world's largest Muslim population of about 205 million people and becoming a potential market for various manufacturers of halal-labeled goods and services. Halal-labeled products are purely about business and should not necessarily be related to religion (Baharuddin et al., 2015).

Muslim consumers have different levels of compliance with sharia depending on the level of trust and religiosity. They will have a positive attitude and an excellent response to halal-labeled products in their marketing process (Karia, 2019). A high level of confidence in halal-labeled products can be a corporate

\footnotetext{
${ }^{*}$ Corresponding Author.

E-mail: hayati.asih@ie.uad.ac.id
}

strategy to achieve a competitive advantage, adapt to market changes, and fulfil

customer demand. The creation of values will then be used to increase the company's productivity and sustainability and ensure the responsible business's operation (Abdul Latiff et al., 2016).

The halal products are not only for Muslim society but also the non-muslim communities. It is because the halal products assure product quality, especially on the contents contained guaranteed to hygiene, which makes halal products can be accepted all groups and cause the product market labeled-halal is growing (Maman et al., 2018). Today, the food industry and the global halal market is the fastest growing business. The need for halal food increases to fulfill people's requirements for animal proteins derived from high nutritious meat. The necessity for animal protein gives industry and livestock businesses great potential to thrive. In 2018, the chicken was the most consumed type in Indonesia than beef and goat (OECD, 2020). The company of chicken farms participates in fulfilling the consumption needs of proteins for the community. It is also a consumption because of the inexpensive cost.

However, China reported to the World Health Organization (WHO) for the first case of new coronavirus infections (2019-Ncov) on December 31, 


\section{TEKNIK, 42 (1), 2021, 88}

2019, that could be infectious and threatening and disruptive to humans (World Health Organization, 2020). Coronavirus novel Sars-CoV-2 causes coronavirus disease. It is a manageable infectious disease identified in December 2019 and was declared a pandemic by WHO on March 11, 2020 (Ghebreyesus, 2020). The Coronavirus outbreak (COVID-19) gave many changes to the pattern of life. The changes not only happen to social activities but also their economic activities.

Existing conditions at this time, the impact of the Coronavirus pandemic or COVID-19 began to be perceived by the most specialized chicken farmers in Yogyakarta, Indonesia. Based on the interview with the business actors directly, the livestock industry's development is currently experiencing a considerable decline. Before the COVID-19 outbreak, its livestock can sell raw chicken meat as much as 50-70 tons per day for traders in the market. However, in the current condition, only able to sell $10-25$ tons per day. The impact of this Wuhan plague made the chicken made distribution messy (Heriyanto, 2020). The situation deteriorated today in making social restrictions on large-scale (SRL), the movement is more tightened so that farmers can not send large quantities to the destination. The decrease in demand for chickens in the Yogyakarta area is caused by some people who are afraid to leave their homes, resulting in the price of plummet and ranchers also have trouble selling.

Based on the survey conducted, the smallmedium enterprise of broiler chickens complained about a decline in broiler chickens' price caused by oversupply in large companies. The large-scale farm restructures the marketing strategy as currently many restaurants, hotels, and some public places in Yogyakarta are close. They sell directly to the market, influencing the small-medium enterprises of broiler chickens sales (Harsono, 2020). Besides, high feed prices are also one of the factors that cause large-scale farms are forced to sell directly to the market. The development of business with the improvement of technology can be a solution during this situation. Supply Chain Innovation application will be a solution to reduce the destructive impact of the COVID-19 outbreak.

Some studies related to this research topic are Pradana, Huertas-García, and Marimon research (Pradana et al., 2020) found that consumers' attitudes towards halal-labeled products can influence intentions to buy products from a subjective perspective (Fritz et al., 2017). Besides, it was also found that the halal food supply chain had a significant and not significant effect on motivation to buy halal food products. However, this study stops at the point of view of motivating influencing behavior so that an imbalance will occur. Further research is required on whether behavior influences increased productivity. The lack of relevant literature shows that halal logistics services have not yet been assessed as a sustainable business source (Formentini \& Taticchi, 2016).

Regarding the current conditions (Armelia et al., 2020), Covid-19 had a negative impact, namely disruption of the supply chain due to disruption in the distribution of day-old chickens, medicinal feed, and broiler farm operational activities. The government's implementation of policies in the context of handling COVID-19 has caused business actors to experience decreased income and difficulties in running their businesses (Kuswantoro \& Alfi, 2020). According to Santoso (2020), meat consumption will increase again after the government relaxes large-scale social restriction policies and adopts a new normal.

Based on the existing research, the researcher found a few research related to the chain of food suppliers that also consider halal and sustainability in the outbreak of Covid-19.

This research aims to analyze the decline in chicken prices, halal sustainability and the concept of marketing strategies impact on the chicken supply chain during the Covid-19 outbreak in Yogyakarta. The first infection was linked (with some but not firmly evidence) to the Huanan seafood market, showing bats as a possible source of SARS-CoV2 as of April 16, 2020 (Wuhan, China) (Li et al., 2020). Halal food is food that is hygienic and good for consumption, the food that is allowed in Islamic sharia and is not a haram food mentioned by Allah in the Qur'an (Alzeer et al., 2018). The increased productivity of sustainability, supply chain, and the halal in the pandemic era is another problem that sectors need to overcome to limit the future's relevant crisis. This study will combine the model with the knowledge to contact the dimension of the halal food supply chain with sustainability and supply chain innovation analysis developed. The combination of these models has a great opportunity in fulfilling the need to address the impact of even more severe losses as the coronavirus outbreak progresses.

Therefore, this study proposes the SEM (Structural Equation Modeling) method as an alternative that is more robust than using multiple regression, path analysis, factor analysis, etc. It is to figure out the current conceptual model. This study analyzes the chicken price reduction and halal product's impact on the chicken business's supply chain during the Covid-19 outbreak in Yogyakarta and halal sustainability and marketing strategies in dealing with the Covid-19 pandemic.

\section{Research Method}

\subsection{Design, location, data sources, population, and sample}

This study uses primary and secondary data. Data processing and analysis use quantitative and descriptive research to provide an overview of the investigated community's phenomena. Further analysis was done by comparing the similarities and differences in these phenomena whether Halal can affect buying 


\section{TEKNIK, 42 (1), 2021, 89}

interest and sustainability of broilers purchases amid the covid-19 pandemic and analysis of the impact of covid during and after a long period. Data collection was conducted from April to June 2020.

Research subjects that researchers use are broiler business actors in Yogyakarta. This research approach uses a grounded theory approach to produce a theory related to the current situation (Tobing et al., 2017). The COVID-19 outbreak in which the broiler farmers are interconnected and involved in response to the events. The determination of breeders, broiler coops traders, and consumers are as data sources. It is based on the involvement of related social entities interconnected in terms of halal and sustainable supply chains before and during the pandemic.

The data collection technique used involved the secondary sector and interview subjects from the point of view of breeders, broiler houses, traders, and consumers. The data collection technique used in the interview is snowball sampling. This sampling technique begins with one person considered the most familiar with this business's development, namely the Yogyakarta City Agriculture and Food Security Service. Besides, the interview was also conducted with the business owner. It is supposed to understand the supply chain structure changes during the Covid-19 outbreak. The data was collected by distributing the 100 questionnaires with the respondents who are the customers who buy chicken. The sample size was determined using the maximum likelihood method estimation with the need for a minimum sample of 100 (Hair et al., 2010).

\subsection{Classification and measurement of variables.}

This study is classified into exogenous variables consisting of the influence of halalness, the effect of online shopping and the consumer's decision to shop for staples on the decline in chicken prices during the pandemic and the endogenous variable which is the aim of the study is the buyer's decision to buy chicken. This study uses a Likert measurement scale containing perceptions through the distance interval between alternative answer choices.

\subsection{Analysis}

Technique The data analysis technique using SEM is carried out to thoroughly explain the relationship between variables in the study using the AMOS SPSS 20 software. The SEM approach was chosen because it is more relevant to the current situation.

\section{Results and Discussion}

\subsection{Impact of covid-19 on broilers}

The Coronavirus outbreak (COVID-19) was discovered for the first time in December in China and has rocked the economy worldwide is no exception to Indonesia. The rupiah, stock indices, domestic consumption of the market, and industrial development in the homeland slowed down. (Troboslivestock, 2020) said that there was a drastic decrease in the purchase of broiler chickens. Apart from falling consumer interest, there have also been reduced market operating hours. Some restaurants and caterers are also not working.

Figure 1 presents the change in structure is affected in other supply chains, resulting in losses caused by small-scale farmers' changes in the supply chain structure of large-scale breeders that took over the market sector to make substantial losses for small farmers. With a reduction in hotel demand, the restaurant then large farms should adapt to cover a considerable loss to take small-scale farms' market share.

Figure 2 presents the process of adaptation undertaken by economic actors as part of the supply chain leads to suppliers' chain changes. In the suppliers' chain, the COVID-19 virus outbreak has a vertical pattern direction that affects the perpetrators of the supplier chain's successive levels, with level integration. On the other hand, during the COVID-19 outbreak, there was a change in the supply chain structure that became horizontally patterned, which adapted to the environmental conditions to suppress the losses incurred due to the effects of the Covid-19 virus. There is a change in the composition of the distribution traffic sequence. Changes in some of such manifestations and restructuration may affect some other process flows of this change due to various pressing factors (Acosta $e t$ al., 2019).

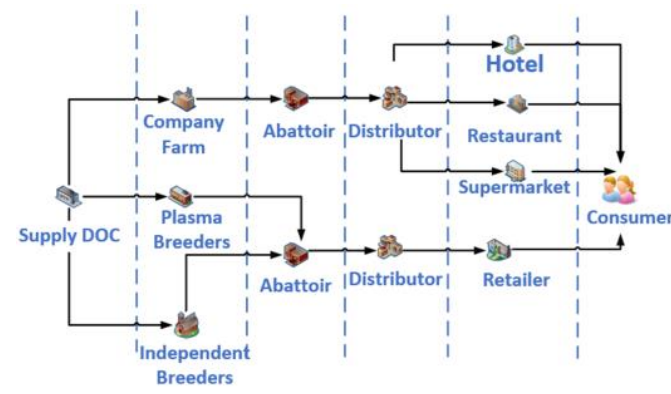

(a)
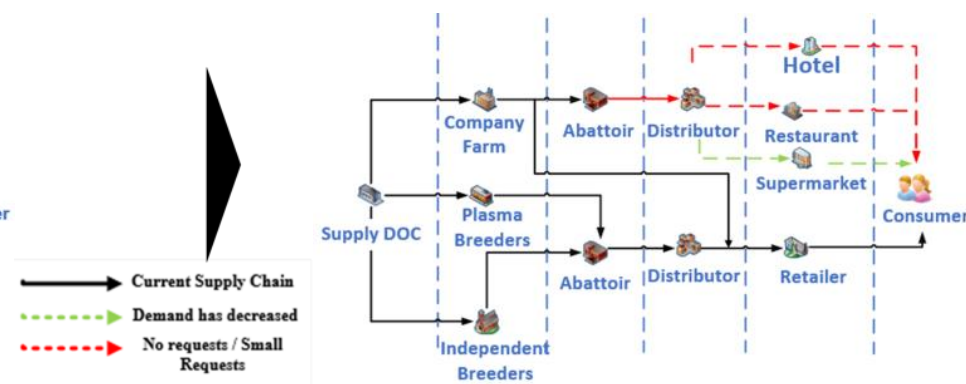

(b)

Figure 1. (a) Before the COVID-19 and (b) during the COVID-19 


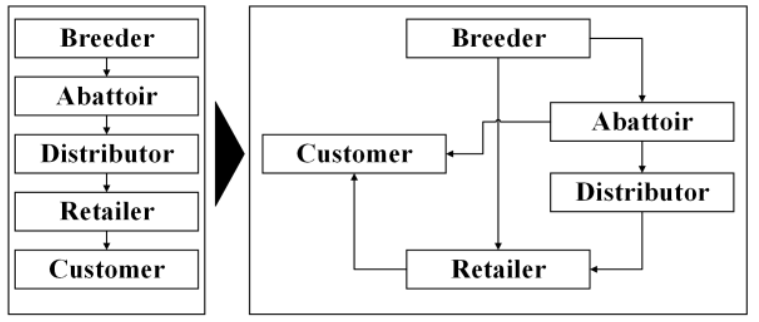

Figure 2. Structural Changes in the Supply Chain.

Besides, the change of supply chain structure that is done by large companies is an adaptation of the continuous strategy section planned so that losses can be minimized due to the selling price is smaller than its maintenance price (Deppermann et al., 2018). The driving factors change the supply chain structure due to the social restriction of large-scale (SRL). The movement is more tightened so that farmers can not send in large quantities to the destination, resulting in the price plummeted. The market's operational time is increasingly restricted so that the onset of panic selling so that farmers struggle to deal.

In addition to the other side of the livestock, actors such as feed manufacturers (Feedmill) also feel the impact. Some feedstuffs that still depend on China's significant imports are constrained supply, logistics, and the price began to increase slowly. illustrated the level of increase in feed prices which is quite significant as shown in Figure 3.

Figure 3 presents as the feed raw material manufacturer, China mastered the global market share around $60-70 \%$, so it affects the logistics of raw materials world feed, and The price continues to crawl up. Due to the outbreak of increasing costs in distributing imported raw materials, the increase is not based on raising tariffs, but because the number of

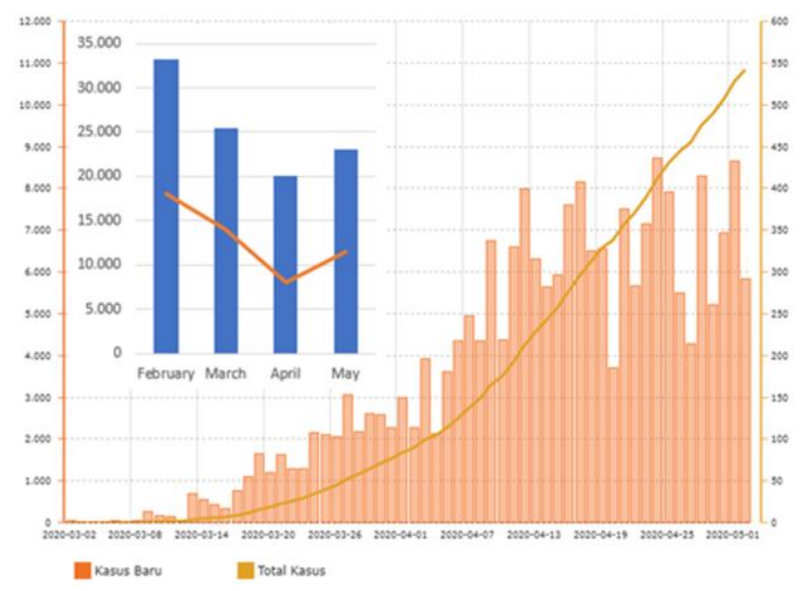

Figure 4. The case was confirmed in Indonesia and the broiler chickens' price index from the influence of the COVID-19 outbreak (Pusat Informasi Harga Pangan Strategis Nasional, 2020).
Total, New Cases Of COVID-19 dan Broiler Price Index (Rp) Resource : Kemenkes RI, 2 May 2020

March $\|$ April $=$ May

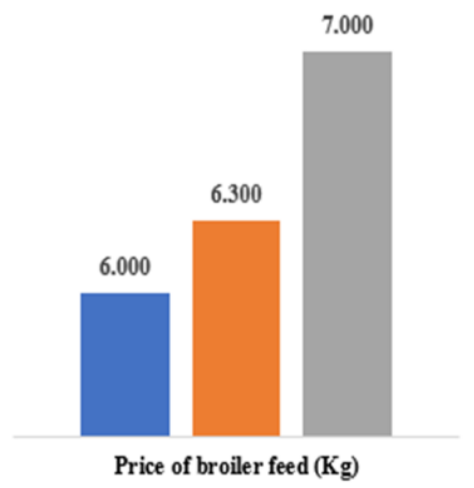

Figure 3. Graph of the price increase of broiler chickens in 2020. (Heriyanto,2020)

circulating goods is reduced. The incidence of certification restriction with the Container began to decrease, resulting in a price increase due to down supply. The level of dependence on China's products is very high. It proved about $75 \%$ of the main supply of feed additive that disturbed its availability in the homeland for feed raw materials alone does not include other products (Troboslivestock, 2020).

The animal food price is creeping up, whereas the demand is decreasing. These results in price drops due to oversupply. Furthermore, there is a low selling price at the farmer level. Therefore, a decrease in selling prices at the farmer level is done to reduce the cost of goods manufactured due to chicken feed.

The graphic in Figure 4 is built with data

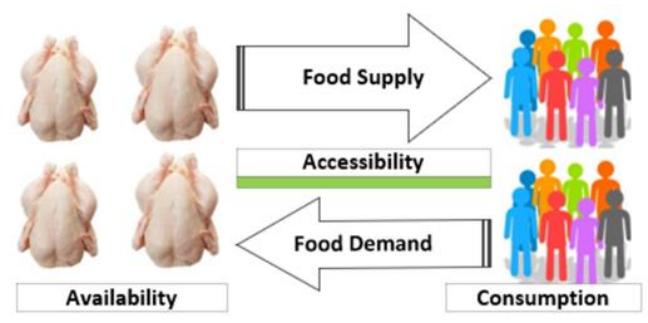

(a)

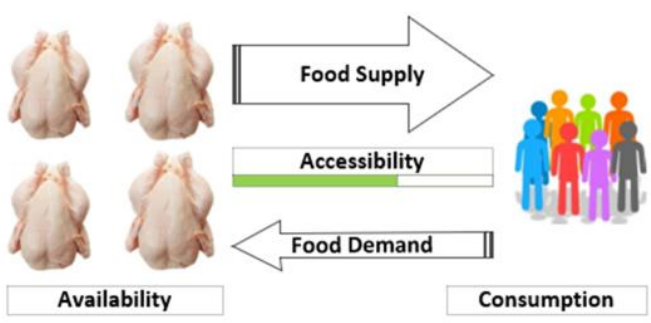

(b)

Figure 5. The accessibility of chicken's supply chain (a) Before the COVID-19 and (b) during the COVID19. 


\section{TEKNIK, 42 (1), 2021, 91}

(updated to May 2, 2020 ) from (Jayani, 2018) and (Pusat Informasi Harga Pangan Strategis Nasional, 2020) for the broiler chicken price index. Chicken price reductions were triggered due to oversupply and lack of market demand due to COVID-19. The impact of this Wuhan plague made the chicken distribution messy. The situation deteriorates today's surplus, being the main cause of the price. Figure 5 presents the accessibility of chicken's supply chain before and during the Covid-19. A decrease in consumer demand, which is inversely proportional to an imbalanced supply, results in an oversupply.

The demand for chicken meat that has continued to decline due to uncertainty and reduced expenditure capacity for savings is due to the Covid-19 outbreak. Already confirmed, there are more than 1,207 workers in the layoffs of a company that was forced to close (Heriyanto, 2020), and this could be worse if the pandemic continued for an extended period due to reduced revenues and continued to suffer losses for the company.

The impact of covid-19 has also led to a policy where schools are dismissed and replaced with studying at home. Therefore many students decide to return to their hometowns. The work from home is a driving factor for decreasing orders for chicken in Yogyakarta, where students become one of the biggest consumers in Yogyakarta.

Figure 6 presents students in Yogyakarta recorded more than 300 thousand students outside of middle and high school student, and only 10-15 percent of students live in Yogyakarta (www.jogja.com, 2016). The return of students and workers who are outside the area of Yogyakarta to the hometown and social restriction of large-scale (SRL), is one of the factors to decline the demand for broiler that causes the restaurants and hotels reduce the demand and even temporarily shut down to minimize the impact of the rising losses. Consequently, oversupply occurs in large enterprises, but Demandnya is reduced (Heriyanto, 2020).

According to the farmers' business, this COVID19 pandemic exacerbates the poultry climate that lowers

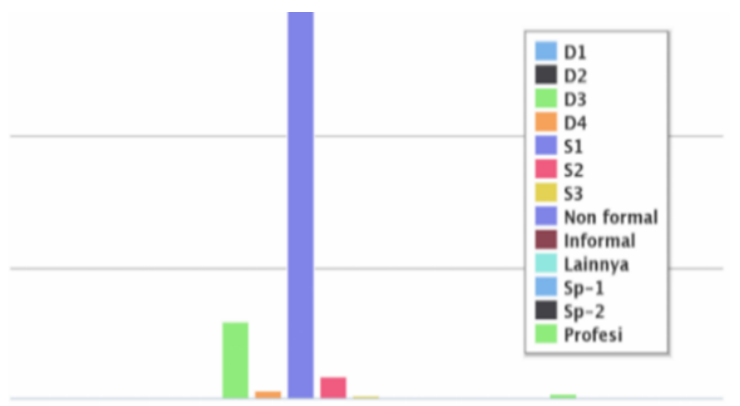

Figure 6. The number of students in Daerah Istimewa Yogyakarta corresponds to the education level (Statistics Center Agency, 2015). community demand, reaching 50\%. Including the decreasing sales to hotels, restaurants, and catering that reaches about $80 \%$, the result is cold storage in $\mathrm{CSH}$ (Chicken Slaughterhouse) so fully charged and the production of breeder pile up because the market does not absorb the maximum.

Figure 7 presents balance of the race is undergoing a surplus of 204,632 tonnes from March to May 2020. This surplus occurred due to the excess or the remaining stock of February last year of 96,640 tons, and the production of March-May of 987,196 tons, while the market needs 881,204 tons (Ditjen PKH, 2020).

\subsection{Analysis of supply chain structures during the covid-19 outbreak}

The supply chain structure analysis will be elaborated in three main aspects: chicken farmers, $\mathrm{CSH}$, and trader side, as explained as follows:

From the farmer's point of view, the losses were quite pronounced due to the selling price not being proportional to the product price, reduced demand, and the existence of an SLR (social restriction on a largescale) policy, which resulted in the cancellation of shipments out of the region, resulting in oversupply. The right step is to reduce the price of broilers in the market.

The CSH (Chicken Slaughterhouse) was not severely lost but only decreased order levels. The CSH distribution system makes to order depending on the order demand. Still, there is always stock for the reserve in case of sudden additions. The decline or price increase is heavily influenced by the CSH strategy to lower the loss rate by rescheduling its working hours.

From the traders' side, the turnover loss is around $50 \%$ before the covid-19 outbreak. Several factors cause the losses: the limitation of market operating hours, the level of demand decreases, along with the decrease in student consumers due to Returning to the hometown of the yard, the presence of work from home urgency and restrictions on leaving the house, thereby reducing the income level of each family. The strategy to reduce the loss rate is to take it directly to the farm and make the deductions to reduce the cost of

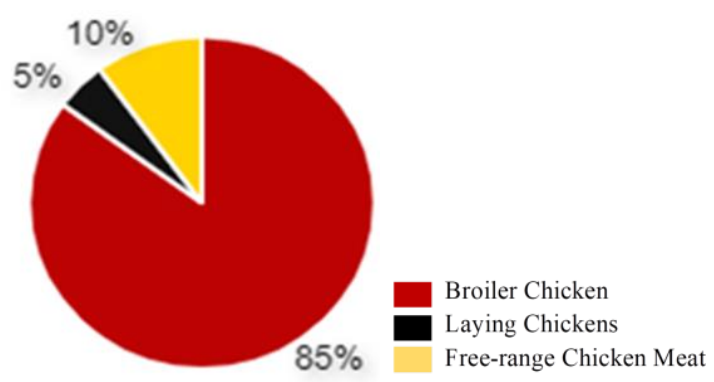

Figure 7. Total production of chicken meat of Indonesia year 2019 that the public meat was pedaling more desirable (Ditjen PKH, 2020) 


\section{TEKNIK, 42 (1), 2021, 92}

Table 1. Validity and Reliability Tests

\begin{tabular}{|c|c|c|}
\hline Variable & Empirical Indicators & $\begin{array}{c}\text { Corrected } \\
\text { item-total } \\
\text { correlation }\end{array}$ \\
\hline \multirow[t]{4}{*}{ Halal } & $\begin{array}{l}\text { Quality and halal assurance are the standards I always apply in considering the } \\
\text { choice of buying halal chicken. }\end{array}$ & 0.643 \\
\hline & $\begin{array}{l}\text { Personal experience is the most important information accurate which I make } \\
\text { as a guideline before buying halal chicken }\end{array}$ & 0.705 \\
\hline & I always consider the halalness of a product before buying it & 0.662 \\
\hline & $\begin{array}{l}\text { halalness has a significant effect on purchasing chicken meat during the } \\
\text { pandemic }\end{array}$ & 0.616 \\
\hline \multirow[t]{4}{*}{ Basic Needs } & $\begin{array}{l}\text { The level of influence of family economic income becomes my consideration } \\
\text { for the decision to buy chicken when a pandemic }\end{array}$ & 0.680 \\
\hline & I always consider the price of chicken before buying it & 0.792 \\
\hline & Price has a significant influence on the decision to choose halal products & 0.736 \\
\hline & $\begin{array}{l}\text { I always consider fulfilling my basic needs by comparing to the chicken price } \\
\text { before buying. }\end{array}$ & 0.715 \\
\hline \multirow[t]{3}{*}{$\begin{array}{l}\text { Online } \\
\text { Shopping }\end{array}$} & $\begin{array}{l}\text { Shop collectively in groups buying to get discounts with several other buyers } \\
\text { in order to get a lower price }\end{array}$ & 0.684 \\
\hline & The online shopping system makes it easy and gives me a sense of security & 0.635 \\
\hline & $\begin{array}{l}\text { Online Shopping / Increased use of delivery services has a significant } \\
\text { influence on the decision to buy chicken meat }\end{array}$ & 0.684 \\
\hline \multirow[t]{5}{*}{ Decision } & halalness has a significant effect on the decision to buy chicken meat & 0.678 \\
\hline & $\begin{array}{l}\text { Online systems can encourage consumer behavior because of a sense of } \\
\text { security and comfort. }\end{array}$ & 0.685 \\
\hline & $\begin{array}{l}\text { My priority is to fulfill basic needs: food (especially durable), fruits, and } \\
\text { medical supplies to be considered before buying chicken meat. }\end{array}$ & 0.609 \\
\hline & Cronbach's Alpha $\quad$ N of Items & \\
\hline & 0.902 & \\
\hline
\end{tabular}

production services at $\mathrm{CSH}$ and make changes to marketing strategies by taking advantage of online sales, providing services directly to consumers.

3.3 Analysis of changes in consumer behavior during a pandemic

According to the interviews conducted, there were changes in consumer behavior patterns when shopping during a pandemic: (1) consumers tend to focus on low prices; (2) consumer Spending Patterns are Centered On Certain Types of Products. Consumers tend to buy basic needs and prioritize food ingredients (especially durable ones) and medical supplies (including masks and hand sanitizers).(3) consumers Prefer Online Shopping; (4) consumers Shop Collectively. Consumers Shop Collectively. (Shop in bulk) for a discounted price.

\subsection{Product differentiation and marketing strategy}

\subsubsection{Validity and reliability tests}

The respondents chosen were chicken consumers who knew the supply chain of halal chicken produced in Yogyakarta. The validity and reliability test results of each item of the research questionnaire are presented in Table 1.

The initial analysis was carried out by testing the validity and Reliability, and all variables met the validity and reliability criteria. According to the data in
Table 1 . The factor loading value is entirely valid if it is more than 0.6 and several variable indicator values that are less than 0.6 or which are not feasible have been issued (McElwee et al., 2017).

This research hypothesis testing is done by looking at the paths in the structural model that are significant. Relationship pathways and significant effects can be seen in the partial path coefficient test, using the statistical t-test (t-test), or looking at the level of significance. The results of the Amos SEM analysis produce the output diagram, which can be seen in Figure 8.

\subsubsection{Assessing the goodness of fit criteria}

Assessing the goodness of fit aims to determine how far the hypothesized model is Fit or fits the sample data based on Chi Square's results.

H0: $\sum=\sum$ (ө) (the model does not match the observational data)

Hi: $=\Theta(\Theta)$ (the model does not match the observation data)

The goodness of fit results are shown in Chi-square 114,777 with df $=72$, and the probability value is 0.001 , which indicates that the value (df) is $114.777 \mathrm{db}$. This means that the hypothesized model has matched the observed data. 


\section{TEKNIK, 42 (1), 2021, 93}

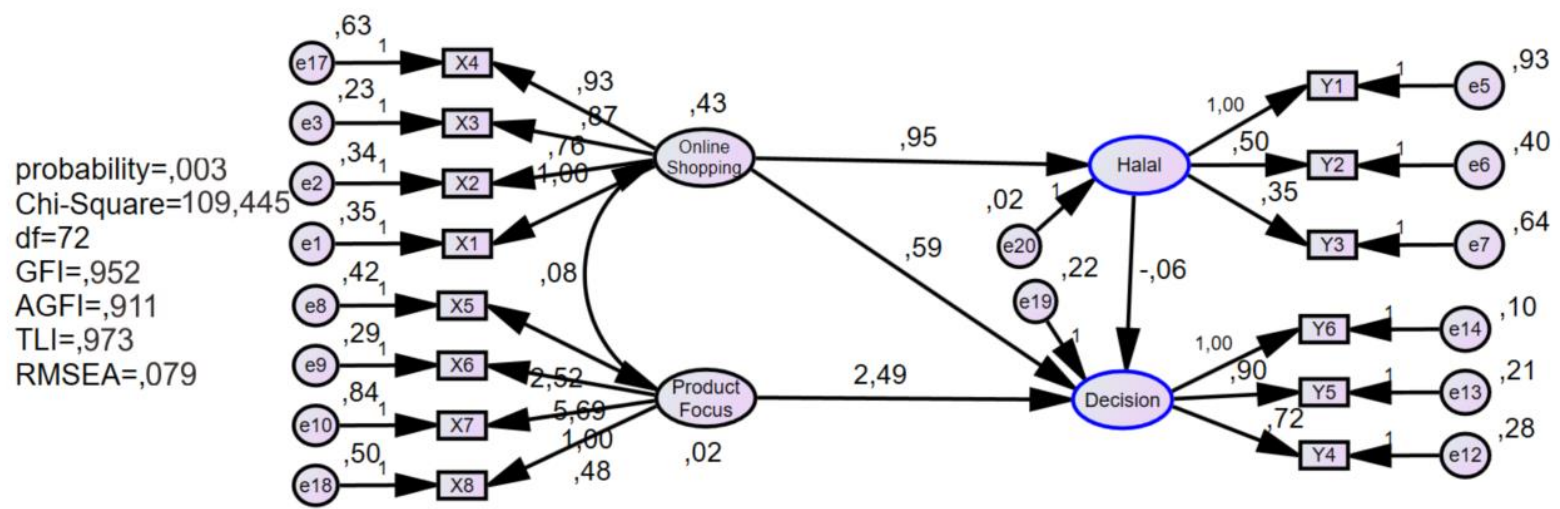

Figure 8. Output diagram

\subsubsection{Analysis of the sampling model}

determination of the reliability test shows the degree to which each indicator indicates a commonly formed variable. The value of construct reliability is at least 0.60 .

$$
\text { Construct Reliability }=\frac{\left(\sum \lambda \mathrm{ij}\right)^{2}}{\left(\sum \lambda \mathrm{ij}\right)^{2}+\sum \mathrm{\epsilon} j}
$$

The evaluation of construct reliability and validity or evaluation of the outer model is as follows.

Sum standardized loading for :

$\begin{array}{lll}\text { Online Shopping } & =1+0.76+0.87+0.93 & =3.56 \\ \text { Basic Needs } & =2.52+5.69+1+0.48 & =9.69 \\ \text { Halal } & =1+0.5+0.35 & =1.85 \\ \text { Decision } & =0.72+0.9+1 & =2.62\end{array}$

Sum measurement error for :

Online Shopping $=0.35+0.34+0.23+0.63=1.55$

Basic Needs $=0.42+0.29+0.84+0.5=2.05$

Halal $\quad=0.93+0.4+0.64=1.97$

Decision $\quad=0.28+0.21+0.1=0.59$

Construct reliability value for each construct :

Online Shopping $=\frac{3.56^{2}}{3.56^{2}+1.55}=0.89$

Fokus Produk $=\frac{9.69^{2}}{9.69^{2}+2.05}=0.97$

Halal

$$
=\frac{1.85^{2}}{1.85^{2}+1.97}=0.63
$$

Decision

$$
=\frac{2.62^{2}}{2.62^{2}+0.59}=0.92
$$

Reliability is generally considered satisfactory if it is above or equal to 0.60 . It can be seen that the construct reliability of each construct has a value above 0.60 . Therefore, it can be concluded that each construct has met the requirements of reability.

Table 2. Path coefficient

\begin{tabular}{cc}
\hline Variable & Path coefficient \\
\hline Online shopping < > Basic Needs & 0.08 \\
Online Shopping < > Halal & 0.95 \\
Online Shopping < > Decision & 0.59 \\
Halal $<$ > Decision & -0.06 \\
Basic Needs < > Decision & 2.49 \\
\hline
\end{tabular}

\subsubsection{Data analysis}

the analysis was performed using the Structural Equation Modeling method with Amos software and produced a plot diagram (Path coefficient). According to the data in Table 2, then the percentage index for each construct is:

Sum of square standardized loading for:

Online Shopping $=12+0.762+0.872+0.932=3.13$

Basic Needs $=2.522+5.692+12+0.482=40.33$

Halal $=12+0.52+0.352=1$

Decision $=0.722+0.92+12=0.26$

Determining the index's percentage by determining the extracted value, if it is high, shows that the indicator has represented the formed variable well. The extracted values are obtained by formula.

$$
\text { Variance Extracted }=\frac{\sum \lambda \mathrm{ij}^{2}}{\sum \lambda \mathrm{ij}^{2}+\sum \mathrm{cj}}
$$

Then the percentage index for each construct is:

Online Shopping $=\frac{3.13}{3.13+1.55}=0.67 \sim 66.89 \%$

Product Focus $=\frac{40.33}{40.3+2.05}=0.95 \sim 95.16 \%$

Halal

$$
=\frac{1}{1+1.97}=0.34 \sim 33.67 \%
$$

Decision

$$
=\frac{0.26}{0.26+0.59}=0.31 \sim 31.29 \%
$$

The decision index in shopping for chicken meat for consumers during the pandemic period was $31.29 \%$ from the calculation process. This value is the lowest value for the decision index, requiring a minimum value of $50 \%$. In the Halal construct, $33.67 \%$ means that halal does not significantly influence chicken meat buying. However, the pattern of consumer spending focused on certain types of products is proven by a percentage of $95.16 \%$, which means that consumers are more likely to identify their basic needs, which are their priority. The consumers' shopping patterns from various generations showed a preference for online shopping. This fact is supported by the percentage index results, which show that $66.89 \%$ prefer shopping online because it is considered safer and more comfortable. Although the level of halalness does not significantly affect 


\section{TEKNIK, 42 (1), 2021, 94}

sustainability for increasing consumer buying decisions, it remains a factor for consumer interest in buying products.

Covid-19 may harm the broiler farm business. However, there are also positive impacts, including the prospect of developing a new lifestyle. The staying-at-home economy will become popular in the future. Working from home, one will still generate income. This is product innovation amid a crisis.

This new lifestyle will give birth to a new marketing strategy. Updates and proper marketing strategies will reduce losses. Changing marketing strategies will help survive this pandemic.

The novelty value given is by changing marketing strategies that will help survive this pandemic. The search for new and more effective marketing strategies that may be implemented should be done. New actions are needed to accelerate the shift in focus towards sustainability and leverage technologies such as the 'Internet of Things' (IoT) to meet objectives (Peralta et al., 2017). The use of technology as a marketing strategy and providing more services for consumers will be a special attraction for consumers to buy products. Taking advantage of technology is to find new business opportunities, namely by implementing an online retail stocking and delivery hub so that consumers can order products without leaving the house. It increased service will attract consumers who are afraid to leave the house, and consumers will feel very safe and comfortable shopping online. The desire to shop online is expected to continue increasing along with personal awareness of avoiding crowds.

The use of third-party services may be an effective solution to reduce the level of losses incurred. The empowerment of online retail stocking and delivery hubs is one of the relevant supply chain innovations developed during the epidemic. This will be the beginning of inspiration for the development of supply chain innovation to become supply chain sustainable.

In addition to production planning improvements, the increase in information exchange in the supply chain can potentially lead to various benefits (Sibomana et al., 2016). The supply chain trend with the impact of Industry 4.0 will be beneficial once the purchase of raw goods and consumers will be

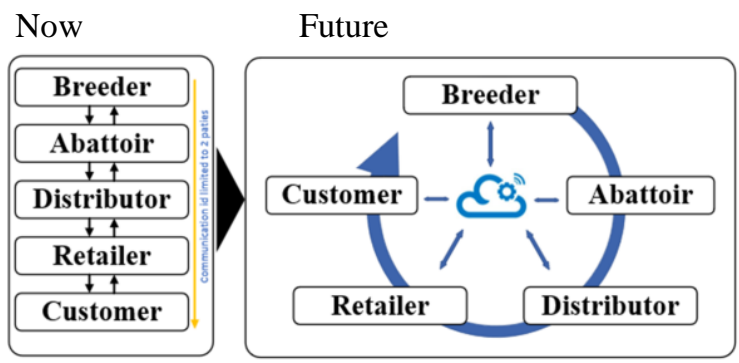

Figure 9. Supply Chain Trend increasingly pampered with the facilities. The following are :

Figure 9 presents benefits in the presence of supply chain trends with IoT and CSR systems have a significant influence on supply chain management. Furthermore, the dissemination of product information will be faster with each other's integrated intersections. More flexible to changes in demand or supply situations. More detailed and accurate integrated system management performance will provide transparency and supply more efficiently than the current system, the selling and revenue rise.

\section{Conclusions}

To minimize the spread of COVID - 19 in Indonesia, the government has a social restriction policy on a large-scale (SRL). Many restaurants, hotels, schools, and campuses are close. Yogyakarta, as a Student City, has a bad impact. Most students were forced to return to their homes from outside of Yogyakarta. This situation makes a decreasing demand, especially for raw chicken meat. On the other hand, the chicken stocks in the chicken farmers are oversupply, so that they are forced to sell the raw chicken meats at a low price. SEM analysis results show that there are changes in consumer behavior where consumers are more concerned with basic needs. There is a new trend in online shopping. This is because consumers feel safer and more comfortable when doing so. This has an indirect impact on changes in the supply chain. Halalness does not affect the increasing of breeder's productivity sustainability. The halal factor does not significantly affect consumer decisions in buying chicken. As a novelty value offered from the results of SEM analysis, it is found that there is an increase in consumers in online shopping, which can make new strategies in marketing strategies. It will help survive this pandemic. The search for new marketing strategies can be applied more effectively. The online empowerment system of stocking retail and delivery hubs has become one of the relevant supply chain innovations developed during this time-after product Innovation services for the prevention needs of COVID -19. Buyers do not need to buy this broiler because it is a product and service innovation that fits into a thriving business today.

\section{Acknowledgments}

The authors would like to thanks Universitas Ahmad Dahlan, Yogyakarta, Indonesia for financial support this research via Grant No PD-219/SP3/LPPMUAD/2020 and also would like to thank the Faculty of Manufacturing Engineering, Universiti Teknikal Malaysia Melaka (UTeM) for their support and cooperation.

\section{References}

Abdul Latiff, Z. A. Bin, Rezai, G., Mohamed, Z., \& 


\section{TEKNIK, 42 (1), 2021, 95}

Amizi Ayob, M. (2016). Food Labels' Impact Assessment on Consumer Purchasing Behavior in Malaysia. Journal of Food Products Marketing, 22(2), 137-146. https://doi.org/10.1080/10454446.2013.856053

Acosta, A., Ihle, R., \& von Cramon-Taubadel, S. (2019). Combining market structure and econometric methods for pricetransmission analysis. Food Security, 11(4), 941-951. https://doi.org/10.1007/s12571-019-00951-w

Alzeer, J., Rieder, U., \& Hadeed, K. A. (2018). Rational and practical aspects of Halal and Tayyib in the context of food safety. Trends in Food Science and Technology, 71(November), 264-267. https://doi.org/10.1016/j.tifs.2017.10.020

Armelia, V., Arkan, N. D., Ismoyowati, I., \& Setianto, N. A. (2020). Dampak sosial ekonomi covid-19 terhadap usaha peternakan broiler di indonesia. Prosiding seminar Teknologi Agribisnis Peternakan (STAP) Fakultas Peternakan Universitas Jenderal Soedirman, vol. 7, 161-167.

Baharuddin, K., Kassim, N. A., Nordin, S. K., \& Buyong, S. Z. (2015). Understanding the Halal Concept and the Importance of Information on Halal Food Business Needed by Potential Malaysian Entrepreneurs. International Journal of Academic Research in Business and Social Sciences, 5(2), 170-180. https://doi.org/10.6007/ijarbss/v5-i2/1476

Badan Pusat Statistik. (2015). Jumlah Perguruan Tinggi, Mahasiswa, dan Tenaga Edukatif (Negeri dan Swasta) di Bawah Kementrian Pendidikan dan Kebudayaan Menurut Provinsi 2013/20142014/2015.

Retrieved fromhttps://www.bps.go.id/statictable/2015/09/14 /1839/jumlah-perguruan-tinggi-mahasiswa-dantenaga-edukatif-negeri-dan-swasta-di-bawahkementrian-pendidikan-dan-kebudayaanmenurut-provinsi-2013-2014-2014-2015.html, 8 May 2020

Deppermann, A., Havlík, P., Valin, H., Boere, E., Herrero, M., Vervoort, J., \& Mathijs, E. (2018). The market impacts of shortening feed supply chains in Europe. Food Security, 10(6), 14011410. https://doi.org/10.1007/s12571-018-0868-2

Direktorat Jenderal Peternakan dan Kesehatan Hewan Kementerian Pertanian. (2020). Kementan: stok pangan asal hewan jelang HBKN aman. Retrieved

fromhttps://ditjenpkh.pertanian.go.id/kementanstok-pangan-asal-hewan-jelang-hbkn-aman, $\quad 8$ May 2020

Formentini, M., \& Taticchi, P. (2016). Corporate sustainability approaches and governance mechanisms in sustainable supply chain management. Journal of Cleaner Production, 112 , 1920-1933. https://doi.org/10.1016/j.jclepro.2014.12.072
Fritz, M. M. C., Schöggl, J. P., \& Baumgartner, R. J. (2017). Selected sustainability aspects for supply chain data exchange: Towards a supply chainwide sustainability assessment. Journal of Cleaner Production, 141, 587-607. https://doi.org/10.1016/j.jclepro.2016.09.080

Ghebreyesus, T. A. (2020). WHO Director-General's opening remarks at the media briefing on COVID-19-11 March 2020. World Health Organization, 11.

Hair, J. F., Black, W. C., Babin, B. J., \& Anderson, R. E. (2010). Multivariate Data Analysis. Ed. 7. Upper Saddle River, NJ: Prentice hall.Int'l: 185.

Karia, N. (2019). Halal logistics: practices, integration and performance of logistics service providers. Journal of Islamic Marketing, November. https://doi.org/10.1108/JIMA-08-2018-0132

Jayani, D.H. (2020) Kasus Covid-19 Bertambah Jadi 10.843 Orang (Sabtu, 2/5). Retrieved from https://databoks.katadata.co.id/datapublish/2020/0 5/02/kasus-covid-19-bertambah-jadi-10843orang-sabtu-25, 9 May 2020.

Kuswantoro, K., \& Alfi, I. (2020). Strategi Keuangan Umkm Cilacap Menghadapi Pandemi Covid 19 (Studi Kasus Umkm Kabupaten Cilacap). Jurnal Teknologi dan Bisnis, 2(1), 40-51. https://doi.org/10.37087/jtb.v2i1.13

Li, Q., Guan, X., Wu, P., Wang, X., Zhou, L., Tong, Y., Ren, R., Leung, K. S. M., Lau, E. H. Y., Wong, J. Y., Xing, X., Xiang, N., Wu, Y., Li, C., Chen, Q., Li, D., Liu, T., Zhao, J., Liu, M., Feng, Z. (2020). Early transmission dynamics in Wuhan, China, of novel coronavirus-infected pneumonia. New England Journal of Medicine, 382(13), 11991207. https://doi.org/10.1056/NEJMoa2001316

Lipka, B. Y. M., \& Hackett, C. (2017). Why Muslims are the world's fastest-growing religious group. Pew Research Cente. Retrieved fromhttps://www.pewresearch.org/facttank/2017/04/06/why-muslims-are-the-worldsfastest-growing-religious-group/, 9 May 2020

Maman, U., Mahbubi, A., \& Jie, F. (2018). Halal risk mitigation in the Australian-Indonesian red meat supply chain. Journal of Islamic Marketing, 9(1), 60-79. https://doi.org/10.1108/JIMA-12-20150095

McElwee, G., Smith, R., \& Lever, J. (2017). Illegal activity in the UK halal (sheep) supply chain: Towards greater understanding. Food Policy, 69, 166-175. https://doi.org/10.1016/j.foodpol.2017.04.006

The Organisation for Economic Co-operation and Development (OECD). (2020). Meat consumption. Retrieved fromhttps://data.oecd.org/agroutput/meatconsumption.htm?context=iLibrary, 7 May 2020.

Peralta, G., Iglesias-Urkia, M., Barcelo, M., Gomez, R., Moran, A., \& Bilbao, J. (2017, May). Fog computing based efficient IoT scheme for the 


\section{TEKNIK, 42 (1), 2021, 96}

Industry 4.0. In 2017 IEEE international workshop of electronics, control, measurement, signals and their application to mechatronics (ECMSM) (1-6). IEEE.

Pusat Informasi Harga Pangan Strategis Nasional. (2020). Perkembangan Harga Pangan Berdasarkan Daerah. Retrieved fromhttps://hargapangan.id/tabel-harga/pasartradisional/daerah, 9 Mei 2020

Pradana, M., Huertas-García, R., \& Marimon, F. (2020). Spanish Muslims' halal food purchase intention. International Food and Agribusiness Management Review, April, 1-14. https://doi.org/10.22434/ifamr2019.0200

www.jogja.com. (2016). Inilah Jumlah seluruh Mahasiswa DIY dan Belanja Bulanannya - Jogja Istimewa.

Retrieved fromhttps://www.jogja.co/inilah-jumlah-seluruhmahasiswa-diy-dan-belanja-bulanannya/, 9 May 2020.

Troboslivestock. Rudi. (2020). Industri Pakan Terdampak Covid-19. April. Retrieved fromhttp://troboslivestock.com/detailberita/2020/04/01/7/12858/industri-pakanterdampak-covid19, 7 May 2020.

Sibomana, M. S., Workneh, T. S., \& Audain, K. (2016). A review of postharvest handling and losses in the fresh tomato supply chain: a focus on SubSaharan Africa. Food Security, 8(2), 389-404. https://doi.org/10.1007/s12571-016-0562-1

Tobing, D. H., Herdiyanto, Y. K., \& Astiti, D. P. (2017). Pendekatan dalam Penelitian Kualitatif. Universitas Udayana. Denpasar: Universitas Udayana. 